\title{
Creating collaboration for contentious projects on managed aquifer recharge: two cases from Finland
}

\author{
Vuokko Laukka $^{1}$ (D) Tapio S. Katko ${ }^{2}$ (D) $\cdot$ Lasse Peltonen $^{3} \cdot$ Riikka Rajala $^{3}$ (D) \\ Received: 25 September 2020 / Accepted: 6 March 2021 / Published online: 6 April 2021 \\ (C) The Author(s) 2021
}

\begin{abstract}
In Finland, community water supply has increasingly relied on natural groundwater and artificially recharged groundwater as the raw water source. Several managed aquifer recharge (MAR) projects have been co-created with involved parties and have proceeded well, while some cases have raised considerable resistance among the stakeholders. It seems that success or failure in MAR cooperation is related to management cultures and the ways in which various interests are taken into account, from the very beginning and throughout the process. Empirically, this paper builds on comparison between two conflictual case studies in Finland: one in the Tampere region and the other in the Turku region. The study analyses the major constraints of these projects through the lens of collaborative rationality, also drawing upon discourse analysis and negotiation theory. The material is gathered through thematic interviews of stakeholders, newspaper articles and a stakeholder workshop. The results indicate that conventional management approaches, drawing from expert-based instrumental rationality, were insufficient in both cases. The collaborative rationality framework suggests that legitimacy for the groundwater projects should be gained through joint knowledge production and inclusive multiparty interaction for creating options for collaboration. Both cases lacked the tools and knowhow for authentic dialogue and collaboration. The emerging paradigm emphasizes more collaborative approaches for natural resources management and urban planning. While MAR projects operate inside these areas and are highly complex in nature, it is essential to embrace the emerging paradigm in order to promote MAR systems along with their huge potential.
\end{abstract}

Keywords Artificial recharge $\cdot$ Collaborative rationality $\cdot$ Finland $\cdot$ Socio-economic factors $\cdot$ Water supply

\section{Introduction}

While the circulation of water in the natural and built environment is reasonably understandable and can be easily explained through maps, diagrams, and tables, the pathways of human

Vuokko Laukka

vuokko.laukka@gmail.com

Tapio S. Katko

tapio.katko@tuni.fi

Lasse Peltonen

lasse.peltonen@uef.fi

Riikka Rajala

riikka.rajala@tuni.fi

1 Finnish Environment Institute SYKE, Latokartanonkaari 11, FI-00790 Helsinki, Finland

2 Tampere University|, Tampere, Finland

3 University of Eastern Finland, Joensuu, Finland affairs are rather difficult to grasp. Indeed, community water systems, including managed aquifer recharge (MAR), can be classified as complex in nature. These systems involve interactions between natural, built and social environments, as well as several networks and stakeholders, which are often competing for a limited and common resource (Islam and Susskind 2013). In addition, actors operate at various levels (local, regional, national and international) and within various development sectors (e.g. agriculture, energy, industry, communication, etc.; Biswas 2004; Ringler et al. 2013).

In their European MAR inventory, Sprenger et al. (2017) identified 224 active MAR sites in 23 countries. Large quantities of drinking water are produced by MAR systems in Finland, France, Germany, Hungary, the Netherlands, Poland, Slovakia, and Switzerland. Besides, MAR has the future potential for reuse and storage of water resources, using nature-based systems. In their attempt to quantify the use of MAR at the global scale, Dillon et al. (2019) point out that MAR is an increasingly important water management strategy, together with demand management, for maintaining, 
enhancing and securing groundwater systems and for protecting and improving water quality. In Finland, the focus country in this paper, the first modern MAR systems were constructed in the 1970s and by 2016 there were altogether 26 MAR systems in operation (Katko 2016). These systems use mostly basin recharge, but also sprinkling irrigation, well injection, and, in a few cases, bank filtration.

Traditionally, the management of modern water systems has emphasized technological and engineering aspects, while not necessarily acknowledging the complexity of the systems and importance of governance experimentation (Bos and Brown 2012). In environmental research, it is common to assume that physical and ecological features of the problem can be separated from their social context (Budds 2009). These features do not exist, however, in a vacuum; therefore, the conventional engineering approach is not applicable to complex problems such as water management schemes that involve several unpredictable, unknowable, and uncontrollable interactions. Water management problems find their way beyond the roles of water professionals only, increasingly requiring an interdisciplinary approach (Freeman 2000), posing challenges to redefine the profession of water managers.

Indeed, while talking about MAR as a response to the global water crisis, this fundamental matter should be acknowledged - for example, the Organisation for Economic Co-operation and Development (OECD 2011) states that the current water crisis is not about water scarcity but about mismanagement, with strong public governance features (see also Carius et al. 2004; Rogers et al. 2006; Saleth and Dinar 2004). Indeed, several international organizations (Food and Agriculture Organization (FAO), UNESCO, International Association of Hydrogeologists (IAH), World Bank (WB) and the Global Environment Facility (GEF)) have addressed the groundwater issues through the governance framework. Groundwater governance can be seen as a complex and over-arching framework of water policies - searching the ways by which strategies are executed and how actors from various fields interact (Groundwater Governance 2016). Dillon et al. (2019) noted that "in recent years, research into governance, operating practices, reliability, economics, risk assessment and public acceptance of MAR has been undertaken".

As a hidden and often overexploited resource, groundwater forms a fruitful arena for debates and conflicts (Jarvis 2014) especially in terms of land use and spatial planning (Cuadrado-Quesada 2014; Salazar et al. 2007; Giordano et al. 2013), social development and equity (Kemper 2003; Linton and Budds 2014) and jurisdictional controversies (Mumme 1982; Zeitoun 2007). Groundwater conflicts and governance have evoked research especially concerning arid and semiarid countries; therefore, it is interesting to analyse the case of Finland, where somewhat water-abundant conditions have not prevented groundwater conflicts. This context introduces an interesting perspective to the discussion about water issues being related to a problem of governance rather than water scarcity.

The purpose of this article is to report new perspectives for groundwater governance by analysing two contentious cases of MAR in Finland. The paper is based on the doctoral dissertation published by the first author (Kurki 2016, the last name is changed to Laukka). The study analysed the major constraints of these projects and reflected on them within the larger context of collaborative rationality framework (Innes and Booher 2016), and finally outlined the lessons for future collaboration. The major research questions are - how collaborative were the processes in the case studies and how were the preconditions for collaboration identified and addressed?

\section{Research methodology, materials and methods}

Twentieth century's policy literature and practice has followed the logic of instrumental rationality which assumes that, through logical steps, experts can gather appropriate data, analyse it objectively, and find the best alternatives to bring to the tables of decision-makers (Islam and Susskind 2013; Innes and Booher 2018). However, the complex world does not follow the logic of a linear model of the universe, and a shift from vertical and hierarchical government to network-like and horizontal governance has emerged (Ansell and Gash 2018; Bodin 2017; Michels and Meijer 2008; Pahl-Wostl et al. 2007; Benz and Papadopoulos 2006). Consequently, new forms of collaborative planning and governance have emerged since the 1980s, building on developments in interorganizational and cross-sectoral public administration (Bryson et al. 2006; Ansell and Gash 2018), and environmental conflict resolution and consensus-seeking negotiation (Susskind et al. 1999a, b, Innes 2004). These approaches seek to tackle complex problems through process designs with horizontal multiparty interaction imbued with a new type of process orientation and mindset, named by planning scholars Judith Innes and David Booher (Innes and Booher 2016) as "collaborative rationality". According to those authors, collaborative rationality, as opposed to instrumental rationality, considers a full range of views and reaches conclusions through shared meaning about their context and the information relevant for the problem. It involves something of a "we are all part of the problem and the resolution" way of thinking. Therefore, a process based on collaborative rationality is inclusive and involves mutual learning and joint reasoning (Innes and Booher 2016).

Building on the notion of collaborative rationality, the conditions, as evaluative criteria for a framework of analysis, are outlined (Table 1). This research analyses two case studies, two inter-municipal MAR projects, both of which may be 
Table 1 Collaborative rationality framework developed from the work of Innes and Booher (2016)

\begin{tabular}{|c|c|}
\hline Condition & Explanation \\
\hline $\begin{array}{l}\text { 1. Inclusion and diversity of the participants and } \\
\text { authentic dialogue }\end{array}$ & $\begin{array}{l}\text { All points of view on the issues are included in the process. Legitimization cannot be reached if } \\
\text { inconvenient opponents are left out from the process. Every participant has an equal right to } \\
\text { speak, to be listened to and to have access to the knowledge on the issues. Skillful management } \\
\text { is needed to assure focus, mutual comprehension and legitimacy of participants' claims. In the } \\
\text { end, conclusions need to be reached and agreements made with shared understanding }\end{array}$ \\
\hline $\begin{array}{l}\text { 2. Emphasis on interests; use of interest-based nego- } \\
\text { tiation (integrative bargaining) }\end{array}$ & $\begin{array}{l}\text { Participants are encouraged to introduce their interests in the issue and discouraged from } \\
\text { position-taking. Once they have gained a broader picture of the situation and they understand } \\
\text { the others' interests as well, they will have a chance to consider new possibilities }\end{array}$ \\
\hline 3. Joint knowledge production & $\begin{array}{l}\text { Expert knowledge as well as community knowledge are both part of the dialogue. Discrepancies } \\
\text { and differences among various knowledge sources are worked through. This may produce } \\
\text { more accurate information than a single study would, but will also legitimize the gained } \\
\text { knowledge, which is crucial to reaching agreements and advancing into taking action }\end{array}$ \\
\hline $\begin{array}{l}\text { 4. Acceptance of creative ideas. Everything is on the } \\
\text { table, enabling creativity. }\end{array}$ & $\begin{array}{l}\text { Impossible or inappropriate ideas are also acknowledged, which may help break a stalemate or at } \\
\text { least generate out-of-the-box thinking and lead to new and unpredictable solutions. This allows } \\
\text { parties to cooperate in ways that enlarge the pie for all }\end{array}$ \\
\hline 5. Satisfying significant concerns of each member & $\begin{array}{l}\text { The substantial concerns of each participant are not only acknowledged, but the group works } \\
\text { through the issues together in order to find ways to satisfy them. Majority rule is not } \\
\text { appropriate as it creates winners and losers. Winners are happy, but losers are likely to sabotage } \\
\text { the next steps of the process }\end{array}$ \\
\hline
\end{tabular}

classified as groundwater conflicts. While the assessment is performed through this framework, discourse- and conflict analysis are used as analysing methods.

In order to lay out the context for the collaborative rationality analysis, characteristics of conflict in the MAR cases were studied using methods of discourse analysis and conflict analysis. Discourse analysis is used to understand how different stakeholders perceive reality and how they participate in the construction and framings of the aims and issues present in MAR projects. It analyses stakeholder perceptions and actions in and through text and talk (Nikander 2008). This research employed two concepts; storyline and discourse coalition, introduced in Hajer's (1995) discursive framework; and further complemented with the idea of knowledge coalition introduced by van Buuren and Edelenbos (2004).

The concept of storyline can be described as a generative narrative which simplifies a phenomenon in order to construct a comprehensible picture of it. Storylines are like discursive cement that keeps a discourse coalition together, while the coalition participates in maintaining and transforming the storyline (Hajer 1995). The formation of coalitions is an eventuality in multi party processes and especially policy coalitions may or may not share discourses. Since knowledge production is an important part of coalition-building, the idea of knowledge coalitions was used in order to complement the analysis of discourse coalition. The idea contributes to the discussion of the transgression of science and society (Delvaux and Shoenaers 2012; Jasanoff and Martello 2004; Nowotny et al. 2001), and moves the focus from between the policy and knowledge worlds themselves to between the coalitions that may include actors from both worlds: for example, citizens, authorities, private sector, and policy-makers (van Buuren and Edelenbos 2004).

While this study utilizes discourse analysis to explore the way different parties see the phenomenon, conflict analysis is used to describe the conflict, central issues and interests of each party. Here the negotiation theory is used in order to analyse the stakeholder interactions. These analyses also bind into the collaborative rationality framework.

Negotiation theory involves two main models of negotiation: distributive and integrative bargaining (Walton and McKersie 1965). The previous includes a strong emphasis on positions, through which parties define their goals and generally engage themselves in a zero-sum negotiation. The main purpose is to defend one's own goals with as minor concessions as possible and to maximize the share of the fixed amount of benefit (Bartos 1995; Fisher et al. 1991). Strong positions overshadow the parties' interests and they are locked in narrow-minded thinking, thus not acknowledging creative new solutions which could satisfy the underlying interests.

Whereas distributive bargaining concentrates on the visible tip of the iceberg, the integrative negotiation approach (also known as principled or interest-based negotiation) emphasizes the underlying interests which can be seen as the $90 \%$ of an iceberg that lies below the surface. According to Fisher et al. (1991) and Susskind et al. (1999a) the goals and positions hide the parties' true interests, the underlying reasons that explain why they take the positions they do. If these interests are revealed, alternative solutions and benefits for all parties can be searched for; thus, this value creation process requires a shift from positional thinking to interest-based negotiation (Islam and Susskind 2013). 
The two cases were studied in parallel by using an overlapping approach: the observations from one case study were compared with the observations from the other during the whole research process. The case studies involved multiple materials, including newspaper articles (approx. 400 articles), stakeholder interviews $(n=45)$, and material gathered from a workshop. Newspaper articles were used as material for the discourse analysis and stakeholder interviews for the conflict analysis. Interviewees were chosen by using a snowball sampling method (Hirsjärvi and Hurme 2011) - key informants were interviewed, and they suggested further interviewees who again suggested more and so on. Altogether, interviews included representatives from all the major stakeholder groups: environmental and municipal authorities, decisionmakers, representatives of a water company, land-owners, representatives of non-governmental organizations (NGOs), and other active citizens.

Based on the interviews, official documents and court decisions, a conflict map was outlined: the case timeline, involved parties, main issues and events of the project. Subsequently, the conflict map was complemented in a workshop, inviting a representative from each stakeholder group. The conflict map was presented and revised together in the workshop and the representatives also had an opportunity to comment on it before and after the workshop. All the material gained from the interviews and the workshop was analysed using the categories of conflict assessment: history, parties, interests, context, and process dynamics (Peltonen and Kangasoja 2009).

\section{Results}

The results of the study are summarized as follows. The first section outlines the basic characteristics of the two cases. While the second section introduces the patterns of the conflict and conditions for collaboration, the third section presents possibilities for future groundwater governance.

\section{What happened in the study cases?}

Natural groundwater and artificially recharged groundwater are commonly used as a raw water source in Finland. Although artificial recharge was tried in Vaasa (western coast) in the late 1920s, wider use of artificial recharge did not start until 1970. In historical perspective, the selection of raw water between ground and surface sources has been an everlasting issue of debate in the country (Katko 2016). Currently, the combined share of the natural groundwater and artificially recharged groundwater supplied is some $66 \%$, out of which $16 \%$ is artificially recharged and $50 \%$ is natural groundwater.

Finland is part of the boreal region having rather abundant water resources. The major groundwater resources, including contributions via MAR, which is mainly used as a water treatment method (Kolehmainen 2008), are located in inland eskers and ice-marginal delta formations (Hatva 1996). The major part of the population is, however, situated in coastal areas; thus, large city centers are often obliged to withdraw groundwater from afar. While crossing municipal borders, tensions between jurisdictional units may occur.

In addition, MAR projects have evoked contradictions related to spatial planning. MAR processes have indirect impacts on land use due to possible restrictions for other land use activities such as gravel mining, plant nursery, or agriculture. Furthermore, MAR processes involve physical land use requirements for different recharge methods such as recharge basins, sprinkling, and recharge wells.

The two cases can be shortly described as follows. The first case is situated in the southwestern coastal Turku Region (later referred as case TRW), and the second in the inland Tampere Region (case Tavase, Fig. 1). They are often referred to as sister-projects - in both cases the growing urban area needs to secure its raw water supply in terms of quality and quantity. Good quality groundwater can be found from the rural area although not in sufficient quantity. The problem could be solved with MAR techniques, although the rural area in question does have adequate groundwater resources for the needs of the local community without using MAR. Thus, the local community does not necessarily have motivation for cooperation, which is a key problem in collective action. In both cases, opposition emerged in the rural areas and led to long litigation processes.

Case TRW started in the 1970s. Turku Region Water company (TRW Ltd) was established in order to withdraw raw water from Lake Pyhäjärvi; however, due to strong opposition the project was voted down in 1993 when new plans were directed towards the MAR project in the same rural region. The opposition continued but after several phases the project got the permission from the Supreme Administrative Court in 2008 and the MAR plant started to operate in 2010.

Case Tavase started in 1993, as the municipalities published the General Plan for water acquisition. In consensus they decided to establish an MAR project, which would be implemented on an esker situated in the rural areas of the region, and managed by a water company called Tavase Ltd. The MAR plant would be constructed on the top of the esker situated in two municipalities, Pälkäne and Kangasala.

In this case the opposition emerged gradually, starting from Pälkäne the only municipality that did not have, nor need, any shares in the project. The opposition was a surprise to the project planners, who were not prepared to respond to these changes in social orders. After years of litigation, the project got a negative decision from the licensing authority in June 2015. However, in 2018, a decision came from the Supreme Court of Administration to continue the permit 


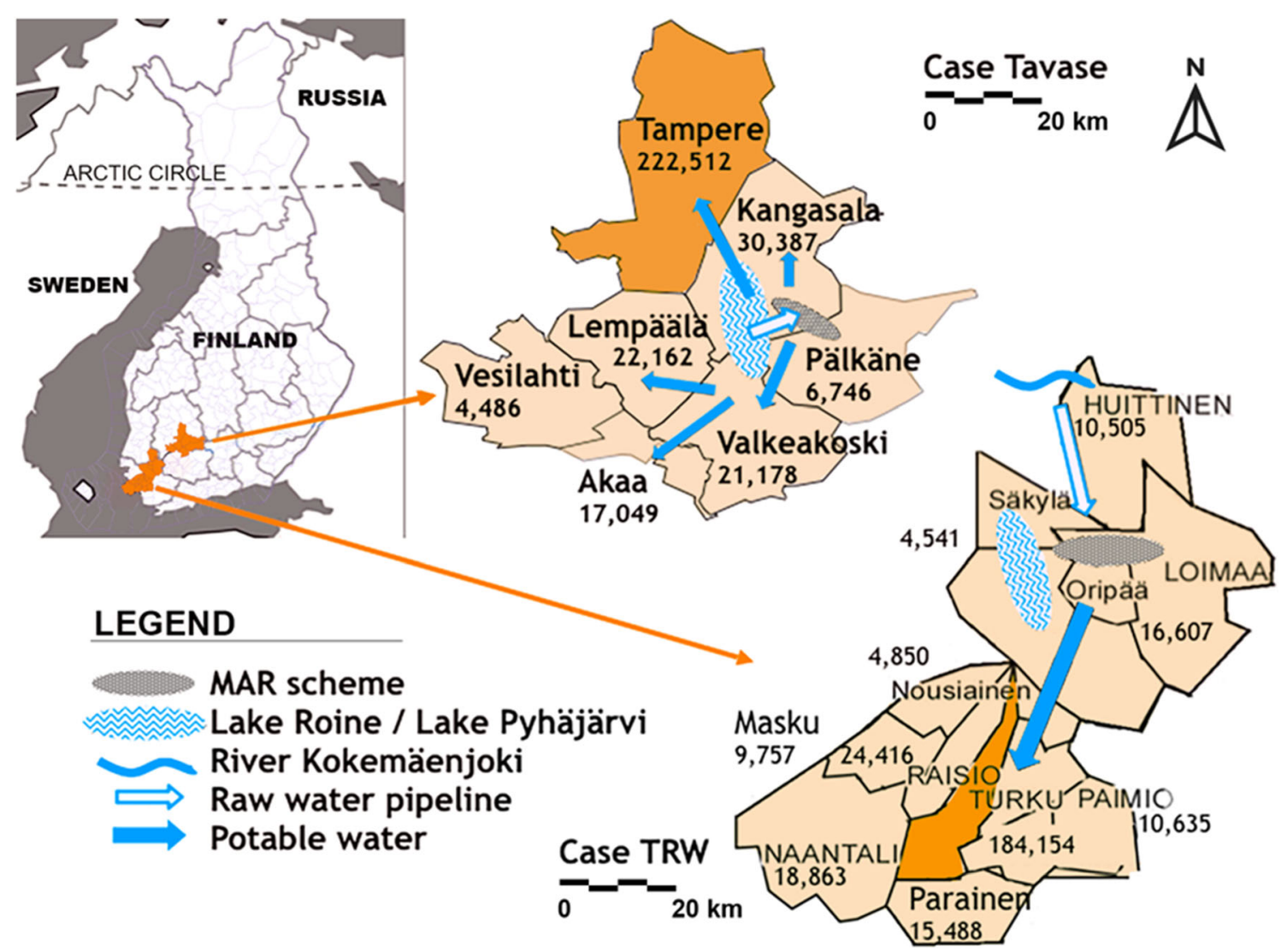

Fig. 1 Geographical locations of the two case studies: Turku Region (case TRW) and Tampere Region (case Tavase) including the numbers of inhabitants of the municipalities (Kurki 2016)

process with the submitted plans in Kangasala municipality. This comprises $70 \%$ of the planned drinking water production. According to the decision, a change of plan is needed for the operations in Pälkäne municipality: it should be ensured that there will be no risks regarding the wellbeing of a nature conservation area. In 2020, the Regional State Administrative Agency gave an additional permission for water production with somewhat limited capacity in Pälkäne municipality. The permit process continues and further decisions are expected in 2021.

The two case studies were selected since they are the largest MAR projects in Finland and they both represent, in the Finnish context, a rather large groundwater conflict, thus forming a fruitful ground for the conflict analysis. In addition, while being sister-projects, they do have interesting differences as well. First, case TRW operates in water-scarce conditions (by Finnish standards), and the case Tavase region is water abundant. Second, according to geographical positioning, only case TRW may be regarded as a long-distance water transfer project, as it is managed and implemented in two separate areas. In case TRW, the municipalities where the MAR plant is situated are not shareholders of the water company, whereas with Tavase Ltd. the municipality of Kangasala is one of its shareholders.

\section{Patterns of conflict and conditions for collaboration}

The discourse analysis of the two cases revealed various storylines related to the projects; however, two of them were interpreted as the most relevant ones: local economy and environmental change storylines, which could both be clearly distinguished in both cases. The latter was chosen because of its' most frequent appearance in the case materials, and the previous because of its' latent relevance. The opponents were afraid that the MAR project would threaten the local economy, e.g. in terms of tighter restrictions concerning other land use activities (such as plant nursery and gravel mining). However, the other storyline was much stronger and supported the hegemonic environmental discourse: the local residents in both cases saw the MAR project as an environmental threat, whereas the project planners saw it as an environmentally friendly solution to water management problem. There was a clear contradiction between the two discourses. The latent local economy discourse indicates economic competition between jurisdictions as well as tensions between rural and urban areas which should be acknowledged in project planning. It also displays a tension between competitive and collaborative tendencies between municipalities. However, the policy decisions were mostly colored by the environmental change 
storyline, especially those aiming at the opposition of the projects.

Despite this positioning, the fault lines of conflict were not formed between experts and lay people. Instead, in both cases, the project opponents included highly educated actors, and they utilized expert-based factual arguments to support their cause. Local residents aligned with expert arguments, favouring research results and outside expertise overclaims relying on local, everyday grounds. They also joined forces with individual groundwater experts who gave their personal support to the opponents. Thus, the formed discourse coalitions can also be called knowledge coalitions (van Buuren and Edelenbos 2004) which move the focus from between the policy and knowledge worlds themselves, to between the coalitions that include actors from both worlds.

In these settings, the preconditions of collaboration for MAR projects are not straightforward to begin with, and they may be further compromised by shortcomings of process design and management. Local opposition can be the result of, or at least fueled by, top-down processes and exclusion of legitimate actors and concerns. An analysis of collaborative rationality, using the framework described in the preceding, points to shortcomings in addressing the conflictual tendencies with better, more collaborative approaches.

First, the diversity of the participants was recognized by the project planners and all the stakeholders were invited to briefings. However, the project planners lacked the management skills for establishing and sustaining an authentic dialogue where mutual comprehension and legitimization of the process could be reached. Instead of being heard and acknowledged, the participants felt that their concerns were neglected. Furthermore, knowledge on various issues was distributed rather openly, but limited access to data, to however small extent, left the opponents distrustful, suspecting that the project planners were hiding something; thereafter, the spiral of distrust deepened.

Second, as opposed to collaborative rationality, the parties adopted a mental model of distributive bargaining and the emphasis was not on exploring interests but, rather, on claims and preestablished positions. The focus in the interactions between parties remained, in a metaphorical sense, on the tip of the iceberg, the visible part of the conflict, while the underlying interests, the fundamental part, were hardly explored to find common ground. Accordingly, in both cases, the environmental argumentation acted as the main discursive cement inside the opposing coalitions and it overshadowed the latent local economy discourse, which revealed some profound concerns and interests of the local residents. Whereas protecting groundwater and the environment was of particular relevance to local actors, the local economy formed one of the main concerns related to the MAR projects. At this point, the planners' professional skills, which leaned on instrumental rationality, did not support a more comprehensive analysis of the case and did acknowledge the interests of the opponents. Instead of acknowledging the interests of the other side and considering new possible ways of thinking, the parties pursued their own goals with a competitive mindset. The project planners were locked into their own positions defined by the water company, and the opposing coalitions, with no access to negotiate with the managers, could not see any other way out than trying to stop the whole project.

Third, the knowledge production process mainly emphasized the highly technical forms of expert knowledge. Community knowledge remained absent from the dialogue, while also the opponents used expert-based argumentation. The discrepancies and differences among various knowledge sources were never worked on together-instead, knowledge coalitions were formed between the opponents and project planners, and neither of them approved the arguments presented by the experts from the other coalition. The situation ended up in a deadlock where the expert-based arguments did not calm down the opposition; instead, it became even stronger. This research, therefore clearly supports the argument presented, for example, by Nelkin (1979), Pellizzoni (2003), and van Buuren (2009): increasing the amount of expert knowledge does not necessarily solve the problem. Indeed, the controversy provided a vivid example of what is referred to as the problem of 'dueling experts' in the literature on sciencebased controversies and remedies such as joint fact-finding (Matsuura and Schenk 2017).

Fourth, the mental model of distributive bargaining and the competitive atmosphere also hindered the possibility of putting everything on the table. Little room for creative problemsolving remained where interests were not openly explored in the first place. The ideas of the other party were neglected and denied because of the fear that any concession to one party would stand for less benefits for the other, revealing an obvious tendency towards a zero-sum game. For example, the opponents did not only oppose the project, but they sought to present alternative ideas and calculations, which were totally ignored by the project planners. Thus, shared out-of-thebox thinking did not occur, and there was no possibility to create new innovative solutions together.

Fifth, satisfying significant concerns of each member could not be reached either. For example, the local residents feared economic losses and environmental impacts that the MAR projects would cause to their municipality, and in both cases, project planners tried to indicate some benefits that local residents would gain from the project and to offer compensation if some unintended effects would occur. However, the compensations were not acknowledged in this competitive atmosphere and mutual trust was already lost: the opponents claimed that these concessions were false or inadequate. There was no place for alternative or creative solutions, which would satisfy the underlying interests of both parties. The distributive bargaining model easily ends up in a deadlock 
or only creates winners and losers; thus, it often destroys relationships and fosters mistrust and hostility (Nolon et al. 2013). Satisfying concerns of each member does not mean, however, that everyone wins (it would be unrealistic); instead, the aim is to enter into an agreement that meets the parties' interests better than if they could not reach an agreement at all (Islam and Susskind 2013).

All the five conditions of the collaborative rationality presented previously were analysed through both cases and the cases were remarkably similar in respect of interaction, knowledge production and argumentation. Thus, the major differences are related to their geographical positioning and the structure of the organization. Regarding case TRW, the opposition was strong and concentrated to the rural area, which is not part of the water company; whereas regarding case Tavase, the gradually emerging opposing coalition formed around three municipalities of which two are shareholders of Tavase Ltd. The latter perhaps gives the opponents a stronger position, and it remains to be seen whether the project will be completed or not.

Finally, the analysis reported here, of collaborative rationality in the two MAR cases, boils down to a demonstration of the continued dominance of a technical, instrumental rationality in the Finnish water sector, with an emphasis mainly on rational expert knowledge, leaving little room for adequately acknowledging concerns in the local socio-economic environment. In the case studies, project planning and management was not able to recognize the complexity of the problem and, thus, the need for collaborative planning. Therefore, the projects were managed predominantly from a technical perspective, while the influence of social orders to water management was underestimated. The planning approaches, based on instrumental rationality, could not successfully operate in the field of complex water management. One of the observations related to the assumption held by many planners - that water management infrastructure, especially a MAR plant, is an environmentally benign service for a local community, and thus welcome - did not hold, and, unable to change course, this led the projects into further acceptability challenges. It is noteworthy that supposedly 'nonpolluting' facilities such as wind power plants have experienced similar opposition in recent decades. However, in some other Finnish MAR cases, not explored in this study, the local socio-economic environment was better acknowledged and no opposition occurred. This is worth further research.

\section{What could have been done otherwise?}

Analysing the challenges that the two MAR projects faced can offer some lessons for future complex groundwater projects. In this section, these lessons are presented and complemented with literature on collaborative rationality.
Whereas the goal of groundwater management based on instrumental rationality is to achieve outcomes that fulfill technical, legislative, and environmental requirements, more collaborative approaches lay greater emphasis on the acceptance and legitimation process. In that process, two major aspects need to be considered-interaction and knowledge production. As the two case studies illustrated, the diversity of the participants might be acknowledged but there are no tools or know-how for authentic dialogue, and thus failed interaction is one of the fundamental constraints for complex groundwater projects and can form an insurmountable barrier between parties. However, if the interaction is successful it can form a bridge even between contentious interests of various parties. According to Innes and Booher (2016) and the collaborative rationality framework, in a collaborative process, acknowledging the concerns of the other side and clarifying the interests of each party would help them to see outside the box (see also Fisher et al. 1991). Thus, parties would start to realize that instead of having a fixed amount of benefits, they have several other options, and it is worth investigating those options before committing to particular solutions. The integrative negotiation model is used in order to produce an agreement between the parties.

Conflictual planning processes show that disagreement on the facts prevails also among the experts themselves. In the case studies, also the opponents invoked authorities who were considered to be experts in the field. This was possible, since, among the experts, MAR was not unambiguously approved as the best water management solution to the areas in question. In the absence of absolute truths and related authority, neither the opponents nor the project planners consider the knowledge produced by the other party as reliable. Instead of duels of experts, this observation should lead to improved deliberation between experts; thus, in the pursuit of collaborative rationality, the main task is to create legitimate and socially robust knowledge jointly with experts and stakeholders (see also: Matsuura and Schenk 2017; Seijger et al. 2016; Islam and Susskind 2013; Ehrmann and Stinson 1999). In this joint knowledge production process, expertise is exploited as a fundamental source of knowledge but it is complemented with local, experiential, and other forms of nonscientific knowledge. The most important question is to find legitimate ways to gather this knowledge base, which then forms a cornerstone for the collectively produced truth about the problem.

In these settings, the role of a water manager should be redefined. Instead of being the holder of the only legitimate source of knowledge, she or he needs to adopt a more facilitative stance, suited to horizontal, collaborative work relations having the key to expert-based knowledge, but could also act as a conveyor, who constructs and maintains the collaborative process and ensures that every relevant stakeholder is at the negotiation table (Innes and Booher 2016). In complex groundwater conflicts, professional facilitators or mediators 
can be contracted to secure trust in the planning process. Here it is important that a mediator has some familiarity with the technical issues and understanding of the substance (Jarvis 2014). With increasing complexity, building a mediation team with complementary skills and expertise may be helpful. Water managers should embrace the idea that in order to reach durable and feasible outcomes in processes, instead of just allowing stakeholders to participate, one really needs them to participate and contribute. Also, participation does not just happen: it needs to be skillfully organized and requires a new, collaboratively rational mindset- the stakeholders should be viewed as partners or allies who are an invaluable asset for dealing with current groundwater management problems that are inherently complex in nature.

\section{Conclusions}

This research analysed two MAR conflicts using the framework of collaborative rationality. Together with discourse and conflict analysis and negotiation theory this led to a comprehensive analysis of the metaphorical iceberg: visible discourses, hidden interests, and the main constraints were revealed. These cases demonstrated the challenges in the conventional way of thinking and management of groundwater, based more on instrumental than collaborative rationality. Tools and practices derived from the conventional management proved inadequate in governing complex MAR issues.

Conventional groundwater management in Finland has not, as of yet, embraced participatory methods, not to mention more advanced approaches and the so-called negotiation dimension (van den van den Hove 2006), which is key in developing genuine and properly designed collaborative planning processes. Rather, the field is largely driven by an assumption of perfect and objective information that can be obtained by expert analysis. However, in complex cases this assumption leads to a deadlock as strong reliance on expert knowledge imposes hierarchical power relations and competition over who is right instead of acknowledging diverse interests and knowledge bases. When facing complexity and conflict, overly rigid expert culture becomes part of the problem instead of the solution.

Evidently, transforming water management practice by implementing collaborative tools includes several practical challenges. To begin with, it remains challenging to persuade every party to negotiate, especially in the situation that has already escalated or been blocked, as it was in both cases here. While a continued stalemate may serve to create enough frustration to drive efforts to break the impasse (Susskind and Cruikshank 1987), conflicts are often met with conflict avoidance, leading to losses of time and money when projects are abandoned. In the absence of a meaningful analysis of the stakeholders, tensions and local concerns, MAR projects and project managers do not have adequate tools to understand the risks and potential costs of conflict (Franks et al. 2014; Susskind and Cruikshank 1987). A clear understanding of the situation, provided by conflict or situation assessments would help managers and stakeholders alike (Susskind et al. 1999b).

Without proper analysis of the possibilities of negotiated agreements, the parties may falsely assume that they are already winning the case and it would be even harmful to start negotiations; they may use the power of not collaborating (Margerum 2002; Margerum and Robinson 2016). Going forward, the emphasis should be further transferred from conflict resolution to collaborative governance where anticipatory work is an essential part (Susskind et al. 2012; Margerum 2011; Innes 2004). Early engagement is often emphasized as necessary in order to achieve durable outcomes (e.g. Cuadrado-Quesada 2014; Nolon et al. 2013; Reed et al. 2006; Chess and Purcell 1999).

Furthermore, many water professionals as well as authorities may avoid collaborative approaches because of their complexity. A collaborative process is likely to be more complex with multiple parties involved than the conventional linear process. In addition, some professionals may fear the loss of authority in informal problem-solving, whereas elected officials may view the consensus-based process as giving up power (Islam and Susskind 2013). The conventional way of thinking is rooted deep in practices and structures of the water management sector as well as in the education of water professionals, thus setting the standard of acting for multiple parties (Innes and Booher 2018). These standards may be difficult to break in individual cases, unless a larger paradigm shift occurs.

The need for more holistic approaches in scientific inquiries and in practice has been acknowledged for decades (Innes and Booher 2018). Conflicts can be seen as anomalies that challenge the prevailing paradigm. Since current ways of thinking and practices of operation no longer provide satisfactory results, both problems and the tools for problem solving need to be redefined. Accordingly, conflicts around the two MAR projects can be seen as challenges to the expert system and prevailing planning paradigm. It seems that the world of water planning and management is balancing between two paradigms - instrumental and collaborative rationality.

The new paradigm can be seen as an addition to the coexisting theoretical sources and practices from the old paradigm (Bäcklund and Mäntysalo 2010). Accordingly, the new paradigm neither discards the old one totally nor offers direct solutions to old problems. Rather, the new collaborative paradigm provides new ways of configuring existing elements such as technical expertise, and assigns them new roles in a restructured process. For example, constructing a water pipeline network to a new residential area within a single local government jurisdiction is not as complex nor as unpredictable a management problem as is an inter-municipal MAR project, involving multiple, interdependent yet autonomous 
actors. Thus, its construction would not require a large-scale collaborative planning and implementation process. Therefore, it is crucial to identify the level of complexity of the problem and analyse the problem thoroughly. This would help in choosing proper management tools and approaches for the planning process. This implies a need for better diagnostics of water management situations and appropriate procedural responses.

Accordingly, the collaborative turn in groundwater governance would introduce processes that reflexively rely on the precepts of collaborative rationality while assigning a new role for expert-based planning not as master but as servant of collaborative work. For example, expert-based knowledge production would continue to serve as a crucial part of the joint knowledge production process in order to answer the question of what is being processed. Instead of pregiven categories of what type of knowledge counts as relevant, collaborative knowledge production would seek to secure the best possible knowledge base with diverse inputs from a range of experts and stakeholders.

The contextual framework of this study lies in the larger context of urban planning as well as natural resources management (NRM), and the findings echo the earlier research on collaborative governance in these fields. Findings from the specific context of groundwater management and MAR, and the Finnish geographical context in boreal regions, demonstrate the need for exchange of experiences between different sectoral, geographical and governance contexts. As the results indicate, context needs to be considered in every analysing process, but the reoccurring characteristics of conflict manifest themselves regardless of contexts. It is hoped that this research contributes to a shared effort of understanding and addressing current challenges in water management, and highlights the need for opening up new methods and paradigms in the face of conflict and complexity.

Funding Open access funding provided by Finnish Environment Institute (SYKE). We wish to acknowledge the VEPATUKI research cluster for the financial support. Lasse Peltonen's contribution has been enabled by the project 'Collaborative remedies for fragmented societies: facilitating the collaborative turn in environmental decision-making', funded by the Strategic Research Council at the Academy of Finland, grant number 313013 .

Open Access This article is licensed under a Creative Commons Attribution 4.0 International License, which permits use, sharing, adaptation, distribution and reproduction in any medium or format, as long as you give appropriate credit to the original author(s) and the source, provide a link to the Creative Commons licence, and indicate if changes were made. The images or other third party material in this article are included in the article's Creative Commons licence, unless indicated otherwise in a credit line to the material. If material is not included in the article's Creative Commons licence and your intended use is not permitted by statutory regulation or exceeds the permitted use, you will need to obtain permission directly from the copyright holder. To view a copy of this licence, visit http://creativecommons.org/licenses/by/4.0/.

\section{References}

Ansell C, Gash A (2008) Collaborative governance in theory and practice. J Public Adm Res Theory 18(4):543-571

Ansell C, Gash A (2018) Collaborative platforms as a governance strategy. J Public Adm Res Theory 28(1):16-32

Bäcklund P, Mäntysalo R (2010) Agonism and institutional ambiguity: ideas on democracy and the role of participation in the development of planning theory and practice - the case of Finland. Plan Theory 9(4):333-350

Bartos OJ (1995) Modeling distributive and integrative negotiations. Ann Am Acad Pol Soc Sci 542(1):48-60

Benz A, Papadopoulos Y (2006) Introduction: governance and democracy-concepts and key issues. In: Benz A, Papadopoulos $\mathrm{Y}$ (eds) Governance and democracy, comparing national, European and international experiences. Routledge, London, pp 1-6

Biswas AK (2004) Integrated water resources management: a reassessment. Water Int 29(2):248-256

Bodin Ö (2017) Collaborative environmental governance: achieving collective action in social-ecological systems. Science 357(6352)

Bos JJ, Brown RR (2012) Governance experimentation and factors of success in socio-technical transitions in the urban water sector. Technol Forecast Soc Chang 79(7):1340-1353

Bryson JM, Crosby BC, Stone MM (2006) The design and implementation of cross-sector collaborations: propositions from the literature. Public Adm Rev 66:44-55

Budds J (2009) Contested H2O: science, policy and politics in water resources management in Chile. Geoforum 40(3):418-430

Carius A, Dabelko GD, Wolf AT (2004) Water, conflict, and cooperation. ECSP Rep 10:60-66

Chess C, Purcell K (1999) Public participation and the environment: do we know what works. Environ Sci Technol 33(16):2685-2692

Cuadrado-Quesada G (2014) Groundwater governance and spatial planning challenges: examining sustainability and participation on the ground. Water Int 39(6):798-812

Delvaux B, Shoenaers F (2012) Knowledge, local actors and public action. Polic Soc 31(2):105-117

Dillon P, Stuyfzand P, Grischek T, Lluria M, Pyne RDG, Jain RC, Bear J, Schwarz J, Wang W, Fernandez E, Stefan C, Pettenati M, van der Gun J, Sprenger C, Massmann G, Scanlon BR, Xanke J, Jokela P, Zheng Y, Rossetto R, Shamrukh M, Pavelic P, Murray E, Ross A, Bonilla Valverde JP, Palma Nava A, Ansems N, Posavec K, Ha K, Martin R, Sapiano M (2019) Sixty years of global progress in managed aquifer recharge. Hydrogeol J 27:1-30. https://doi.org/10. 1007/s10040-018-1841-z

Ehrmann JR, Stinson BL (1999) Joint fact-finding and the use of technical experts. In: Susskind L, McKearnan S, Thomas-Larmer J (eds) Consensus building handbook, a comprehensive guide to reaching agreement. Sage, Thousand Oaks, CA, pp 375-399

Fisher R, Ury W, Patton B (1991) Getting to yes: negotiating an agreement without giving in, 2nd edn. Penguin, New York

Franks DM, Davis R, Bebbington AJ, Ali SH, Kemp D, Scurrah M (2014) Conflict translates environmental and social risk into business costs. Proc Natl Acad Sci 111(21):7576-7581

Freeman D (2000) Wicked water problems: sociology and local water organizations in addressing water resources policy. J Am Water Resour Assoc 36(3):483-491

Giordano RD, Agostino D, Apollonio C, Lamaddalena N, Vurro M (2013) Bayesian belief network to support conflict analysis for groundwater protection: the case of the Apulia region. J Environ Manag 115:136-146

Groundwater Governance (2016) Groundwater policy and governance. Digest of Thematic Paper 5. https://www.un-igrac.org/sites/default/ files/resources/files/GW\%20Governance-eng-v5.pdf. Accessed March 2021 
Hajer M (1995) The politics of environmental discourse: ecological modernisation and the policy process. Clarendon, Oxford

Hatva T (1996) Artificial groundwater recharge in Finland. In: Kivimäki A-L, Suokko T (eds) Artificial recharge of groundwater. Proceedings of an International Symposium, Helsinki, Finland, June 3-5, 1996, pp 3-12

Hirsjärvi S, Hurme H (2011) Tutkimushaastattelu. Teemahaastattelun teoria ja käytäntö [Research interview: theme interview theory and practice]. Gaudeamus, Helsinki University Press, Helsinki

Innes JE (2004) Consensus building: clarifications for the critics. Plan Theory 3(1):71-92

Innes J, Booher D (2018) Planning with complexity. An introduction to collaborative rationality for public policy, Second Edition, Routledge, London

Innes J, Booher D (2016) Collaborative rationality as a strategy for working with wicked problems. Landsc Urban Plan 154:8-10

Islam S, Susskind L (2013) Water diplomacy, a negotiated approach to managing complex water networks. Routledge, New York

Jarvis TW (2014) Contesting hidden waters: conflict resolution for groundwater and aquifers. Routledge, New York

Jasanoff S, Martello M (eds) (2004) Earthly politics: local and global in environmental governance. MIT Press, Cambridge, MA

Katko TS (2016) Continuous Debate: Selection of Appropriate Raw Water Source. In: Finnish Water Services - Experiences in Global Perspective. Finnish Water Utilities Association. Co-published by IWA Publishing, p. 58-67

Kemper KE (2003) Rethinking groundwater management. In: Figuères C, Tortajada C, Rockström J (eds) Rethinking water management: innovative approaches to contemporary issues. Earthscan, London, pp 120-143

Kolehmainen R (2008) Natural organic matter biodegradation and microbial community dynamics in artificial groundwater recharge. $\mathrm{PhD}$ thesis, Tampere University of Technology, Tampere, Finland

Kurki V (2016) Negotiating groundwater Governance: lessons from contentious aquifer recharge projects. $\mathrm{PhD}$ Thesis, Tampere University of Technology, Tampere, Finland. https://trepo.tuni.fi//handle/ 10024/115229. Accessed March 2021

Linton J, Budds J (2014) The hydrosocial cycle: defining and mobilizing a relational-dialectical approach to water. Geoforum 57:170-180

Margerum R (2002) Collaborative planning: building consensus and building a distinct model for practice. J Plan Educ Res 21(3):237253

Margerum R (2011) Beyond consensus: improving collaborative planning and management. MIT Press, Cambridge, MA

Margerum R, Robinson C (eds) (2016) The challenge of collaboration in environmental governance, barriers and responses. Edward Elgar, Cheltenham, UK

Matsuura M, Schenk T (eds) (2017) Joint fact finding in urban planning and environmental disputes. Routledge, London

Michels A, Meijer A (2008) Safeguarding public accountability in horizontal government. Public Manag Rev 10(2):165-173

Mumme SP (1982) The United States - Mexico groundwater dispute: domestic influence on foreign policy. $\mathrm{PhD}$ thesis, University of Arizona, Arizona, USA

Nelkin D (ed) (1979) Controversy: politics of technical decisions. Sage, Thousand Oaks, CA

Nikander P (2008) Constructionism and discourse analysis. In: Holstein JA, Gubrium JF (eds) Handbook of constructionist research. Guilford, New York, pp 413-428

Nolon S, Ferguson O, Field P (2013) Land in conflict: managing and resolving land use disputes. Lincoln Institute of Land Policy, Cambridge, MA

Nowotny H, Scott P, Gibbons M (2001) Re-thinking science. Knowledge and the public in an age of uncertainty. Polity Press, Cambridge, UK
OECD (2011) Water governance in OECD countries. OECD Studies on water, OECD Publishing, Paris, A multi-level approach. https://doi. org/10.1787/9789264119284-en

Pahl-Wostl C, Craps M, Dewulf A, Mostert E, Tabara D, Taillieu T (2007) Social learning and water resources management. Ecol Soc 12(2):5 https://www.jstor.org/stable/26267868. Accessed March 2021

Pellizzoni L (2003) Knowledge, uncertainty and the transformation of the public sphere. Eur J Soc Theory 6(3):327-355

Peltonen L, Kangasoja J (2009) Konfliktien kartoitus suunnitelun apuvälineenä [Conflict mapping as a planning tool]. Yhdyskuntasuunnittelu 47(4):88-97

Reed MS, Fraser EDG, Dougill AJ (2006) An adaptive learning process for developing and applying sustainability indicators with local communities. Ecol Econ 59(4):406-418

Ringler C, Bhaduri A, Lawford R (2013) The nexus across water, energy, land and food (WELF): potential for improved resource use efficiency? Curr Opin Environ Sustain 5(6):617-624

Rogers D, Llamas RM, Cortina LM (eds) (2006) Water scarcity: myth or reality. Balkema, Amsterdam

Salazar R, Szidarovszky F, Coppola E, Rojano A (2007) Application of game theory for a groundwater conflict in Mexico. J Environ Manag 84:560-571

Saleth RM, Dinar A (2004) The institutional economics of water, a crosscountry analysis of institutions and performance. Edward Elgar, Cheltenham, UK

Seijger C, Otter HS, van Tatenhove J, Dewulf G (2016) Socially robust knowledge in coastal projects. Environ Sci Policy 55(part 3):393407. https://doi.org/10.1016/j.envsci.2015.03.004

Sprenger C, Hartog N, Hernández M, Vilanova E, Grützmacher G, Scheibler F, Hannappel S (2017) Inventory of managed aquifer recharge sites in Europe: historical development, current situation and perspectives. Hydrogeol J 25:1909-1922. https://doi.org/10.1007/ s10040-017-1554-8

Susskind L, Cruikshank J (1987) Breaking the impasse: consensual approaches to resolving public disputes. Basic Books, New York

Susskind L, McKearnan S, Thomas-Larmer J (eds) (1999a) Consensus building handbook, a comprehensive guide to reaching agreement. Sage, Thousand Oaks, CA

Susskind L, Thomas-Larmer J, McKearnan S (1999b) Conducting a conflict assessment. In: Susskind L, McKearnan S, Thomas-Larmer J (eds) Consensus building handbook: a comprehensive guide to reaching agreement. Sage, Thousand Oaks, CA, pp 99-136

Susskind L, Camacho AE, Schenk T (2012) A critical assessment of collaborative adaptive management in practice. J Appl Ecol 49(1): 47-51

van Buuren A (2009) Knowledge for governance, governance of knowledge: inclusive knowledge management in collaborative governance processes. Int Public Manag J 12(2):208-235

van Buuren A, Edelenbos J (2004) Conflicting knowledge: why is joint knowledge production such a problem? Sci Public Policy 31(4): 289-299

van den Hove S (2006) Between consensus and compromise: acknowledging the negotiation dimension in participatory approaches. Land Use Policy 23(1):10-17

Walton R, McKersie R (1965) A behavioral theory of labor negotiations. ILR, Ithaca, NY

Zeitoun M (2007) The conflict vs. cooperation paradox: fighting over or sharing of Palestinian-Israeli groundwater? Water Int 32(1): $105-120$

Publisher's note Springer Nature remains neutral with regard to jurisdictional claims in published maps and institutional affiliations. 